\title{
The Production of Hydroxyapatite Prototypes from Solid Bodies of Gypsum/Polyvinyl Alcohol Composites
}

\author{
Amanda Alves Barbosa, Andréa de Vasconcelos Ferraz*, \\ Alan Christie Dantas, Nelson Cárdenas Olivier \\ Universidade Federal do Vale do São Francisco - UNIVASF, \\ Av. Antonio Carlos Magalhães, 510, Country Club, CEP 48902-300, Juazeiro, BA, Brasil
}

Received: June 20, 2013; Revised: April 5, 2014

\begin{abstract}
Prototypes of porous hydroxyapatite (HAp) were produced from Gypsum/PVA composite, using a mass proportion of $15 \%$ polymer. The material was obtained by means of chemical conversion in $\left(\mathrm{NH}_{4}\right)_{2} \mathrm{HPO}_{4} 0.5$ mol.L $\mathrm{L}^{-1}$ solution and $\mathrm{NH}_{4} \mathrm{OH} 6.0$ mol.L $\mathrm{L}^{-1}$ alkaline medium for $\mathrm{pH}$ control, maintained between 6.0 and 9.0. The reaction occurred at a temperature of $100^{\circ} \mathrm{C}$ at different test times. The obtained HAp was characterized by several techniques, such as FTIR, which identified the $\mathrm{SO}_{4}{ }^{2-}$ groups characteristic for the Gypsum block, and the $\mathrm{PO}_{4}{ }^{3-}$ groups that are attributed to the biomaterial HAp, besides XRD and SEM, which made it possible to confirm a successful conversion of the material. Tests for mechanical resistance to compression $\left(\sigma_{\mathbf{c}}\right)$ were carried out for both materials as well.
\end{abstract}

Keywords: hydroxyapatite, gypsum, PVA, prototypes

\section{Introduction}

Synthetic or natural calcium phosphates are widely used in the biomedical area to repair loss of bone tissue due to their extensive compatibility ${ }^{1}$. $\mathrm{HAp}\left[\mathrm{Ca}_{10}\left(\mathrm{PO}_{4}\right)_{6}(\mathrm{OH})_{2}\right]$ figures among the phosphates of greatest interest, as it is a biomaterial that has chemical and crystallographic similarity to the human bone matrix ${ }^{2}$. Due to its chemical similarity to the host tissue, HAp has the ability to bind to the host, once it consists of calcium and phosphate ions, which actively participate in the ionic equilibrium between the biological fluids and the implanted ceramic ${ }^{3}$. However, HAp is a brittle material and therefore its applications are limited, e.g. preventing its use in areas of high mechanical strain. For this reason, HAp is used mainly as a coating, generally over metals such as titanium and its alloys, or stainless steel ${ }^{4}$, besides its use as bone void filler ${ }^{5}$.

Regarding HAp in block shape, different production methods are in use, which, however, result in a dense block, yielding a product that is difficult to conform which also lacks sufficient porosity, therefore making the growth of bone tissue inside the implant impossible. The synthesis of porous HAp blocks is also realized, yet in general, marine corals are used, which consist of calcium carbonate and are chemically converted into HAp, preserving the porous structure of the coral ${ }^{6}$.

The development of solid bodies of HAp, with previously defined forms and considerable porosity, using a raw material of high purity and of great abundance in the region, is the aim of this work. The raw material in this case is gypsum $\beta$, calcium sulfate hemihydrate $\left[\mathrm{CaSO}_{4} \cdot 0.5 \mathrm{H}_{2} \mathrm{O}\right]$. Besides having the advantage of high purity and low cost, this raw material shows an excellent moldability when in

*e-mail: andrea.ferraz@univasf.edu.br paste form, thus allowing the obtainment of solid bodies in previously defined shapes ${ }^{7,8}$. The use of gypsum in the production of HAp results in a high value added, seeing that the obtained ceramic has a quite elevated cost when compared to gypsum, considering the value of $5.0 \mathrm{~g}$ of $99.9 \%$ pure HAp to be $\mathrm{R} \$ 125.12^{[9]}$, while a $40 \mathrm{~kg}$ sack of gypsum $\beta$ costs on average $\mathrm{R} \$ 18.00^{[10]}$.

The formation of porous solid bodies of HAp results from the chemical conversion of porous gypsum bodies, which are obtained by adding the polymer polyvinyl alcohol (PVA) to the gypsum powder, seeing that the former is an agglutinating polymer, highly soluble in water ${ }^{11}$ and therefore easily removed from the block, leaving pores as a result.

\section{Material and Methods}

\subsection{Production of porous solid bodies}

The gypsum $\beta$ ( 80 to $95 \%$ of purity) used to obtain the Gypsum/PVA composite was supplied by Gesso Mineral Industry, a company belonging to the gypsum pole of Araripe, Pernambuco state, whereas the PVA (99\% hydrolyzed, melting point $>113^{\circ} \mathrm{C}$ and density $1.269 \mathrm{~g} / \mathrm{cm}^{3}$ ) was supplied by Aldrich (USA). The gypsum was characterized using X-ray diffraction (XRD) (Diffract ACT series 1000 SIEMENS, radiation $\mathrm{Cu}-\mathrm{K} \alpha$ ), Scanning Electron Microscopy (SEM) (HITACHI, TM-1000; Tabletop Microscope) and Fourier Transform Infrared Spectroscopy (FTIR) (Bruker I model FS66). After the characterization of the raw material, the Gypsum/PVA blocks were prepared by molding the paste. The composite was obtained from the mixture of the powders (gypsum and PVA) in proportions 
of $1,5,10$ and $15 \%$ of polymer weight, which were then powdered on the surface of the water (NBR 12129) ${ }^{7}$, at a water/gypsum ratio (w/g) of 0.5 to 0.7 . Mechanical strength tests $\left(\sigma_{\mathbf{c}}\right)$ were carried out with the composite blocks, aiming to evaluate which quantity of polymer added to the gypsum would obtain the best mechanical properties of the block. Afterwards, the blocks with the defined PVA percentage were cured and then submersed in water for approximately 2 hours, at a temperature of $90^{\circ} \mathrm{C}$, in order to solubilize the polymer in the blocks which results in the desired porosity.

\subsection{Conversion of porous bodies into hydroxyapatite}

Porous gypsum blocks were submersed in $200 \mathrm{~mL}$ of $\left(\mathrm{NH}_{4}\right)_{2} \mathrm{HPO}_{4} 0.5 \mathrm{~mol} . \mathrm{L}^{-1}$ solution in a three-neck flask at a temperature of $100^{\circ} \mathrm{C}$ at different reaction times $(8$, 24 and 36 hours). The $\mathrm{pH}$ of the medium was controlled by adding $\mathrm{NH}_{4} \mathrm{OH} 6.0$ mol. $\mathrm{L}^{-1}$ solution. At the end of the reaction time, the blocks were washed in de-ionized water until reaching neutral $\mathrm{pH}$ and then dried in an oven at $50^{\circ} \mathrm{C}$ for approximately 4 hours. The material obtained from the conversion was initially characterized by analyzing its morphology as to block fracture using Scanning Electron Microscopy (SEM), while the chemical elements present in the sample were verified by Energy Dispersive Spectroscopy (EDS) coupled to SEM. Using FTIR, the samples were prepared as $\mathrm{KBr}$ pellets pressed in vacuum, and the absorption bands related to the present compounds were obtained. The XRD with diffractograms recorded in steps of $0.02^{\circ}$ at $2 \theta$ and integration time of 1 s per step showed the different crystalline phases of the obtained material.

\subsection{Mechanical characterization of G/PVA compounds, porous gypsum and hydroxyapatite bodies}

The solid bodies of G/PVA composite (1, 5, 10 and 15\% of polymer), porous gypsum and porous HAp were evaluated as to their mechanical behavior carrying out compression strength tests $\left(\sigma_{\mathrm{c}}\right)$. The dimensions of the used cylindrical bodies were $11 \times 22 \mathrm{~mm}$ and the tests were carried out in a Universal Mechanical Testing Machine (EMIC-DL 10000). The geometrical porosity of the bodies was calculated using Equation $1^{12}$, where $\varepsilon$ is the porosity, $\varphi_{\mathrm{g}}$ is the geometric density, and $\varphi_{\mathrm{s}}$ is the specific density of the solid.

$\varepsilon(\%)=1-\left(\varphi_{\mathrm{g} /} \varphi_{\mathrm{s}}\right) \times 100$

For the machining of the gypsum/PVA composite a lathe (Nardini, MS.220.G F2 KJL 919) was used, obtaining prototypes of a variety of screw-shaped models.

\section{Results and Discussion}

\subsection{Characterizations of the raw material and the Gypsum/PVA composite}

The Gypsum/PVA composites prepared at w/g ratios of 0.5 and 0.6 showed low moldability of the paste which made the molding of solid bodies more difficult. Therefore the ratio 0.7 was chosen as standard for all samples.

Figure 1a shows the morphology of a fracture in a dihydrate gypsum block. Its microstructure consists of crystals in prismatic needle shape. The EDS analysis, shown in Figure 1b, confirms the high purity of the hemihydrate.

Observing the morphology of the G/PVA composite $(15 \%)$ in Figure 2a, it can be verified that the PVA phase, due to its solubility in water, provides the formation of a homogenous material. A slight change in the size and form of the crystals can be observed, which might be related to the hydrophilic nature of $\mathrm{PVA}^{13,14}$, seeing that such a characteristic enables a larger interaction of the polymer with the hydration water used to prepare the composite paste. For this reason, the dihydrate crystals show better adherence to the PVA grains, causing greater interaction between crystals and polymer particles ${ }^{15}$. This fact also explains the higher mechanical resistance shown by this material, which increases accordingly to the increase in percentage of polymer, as shown in Figure 3a. Regarding the composite after the removal of the PVA (Figure 2b), no significant variation in material morphology was verified, although the

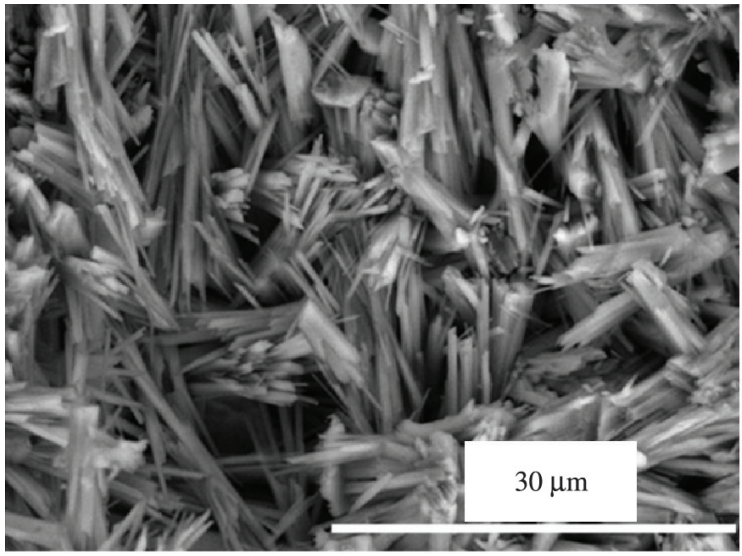

(a)

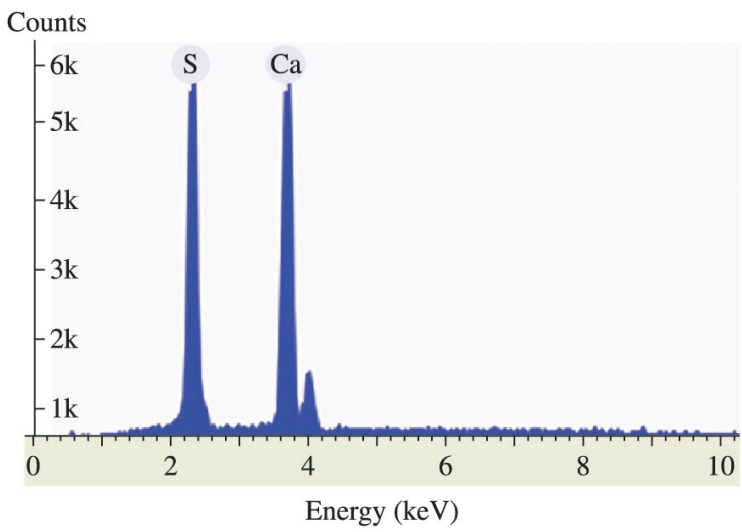

(b)

Figure 1. a)Micrograph of the fracture of a dihydrate gypsum block and b)EDS of the gypsum sample shown in Figure 1a. 


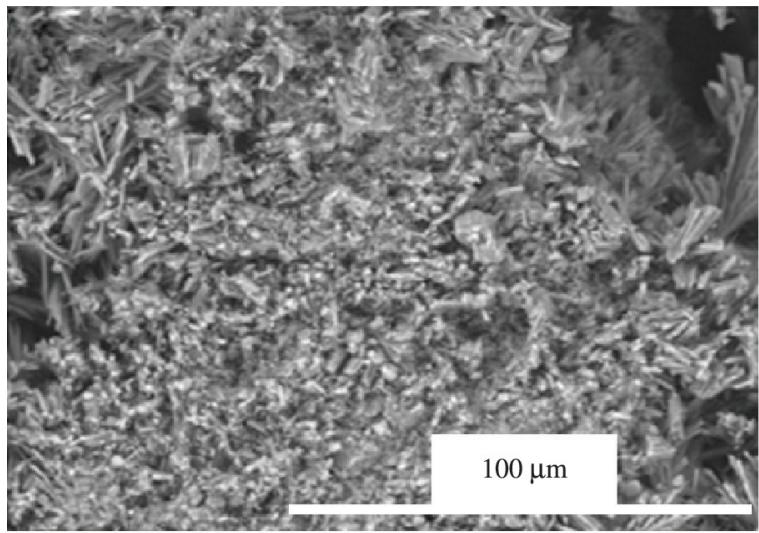

(a)

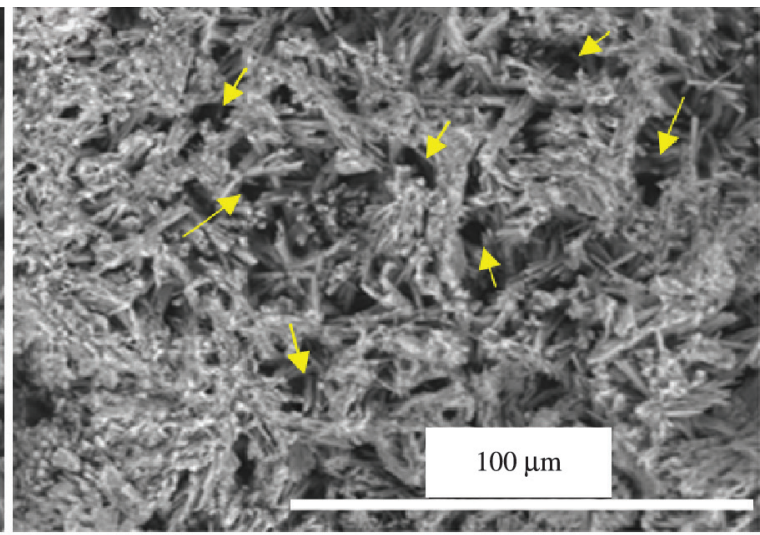

(b)

Figure 2. Micrographs of a fracture area of G/PVA composite. a)Before the removal of PVA and b)Arrows indicating pores formed by the removal of PVA.

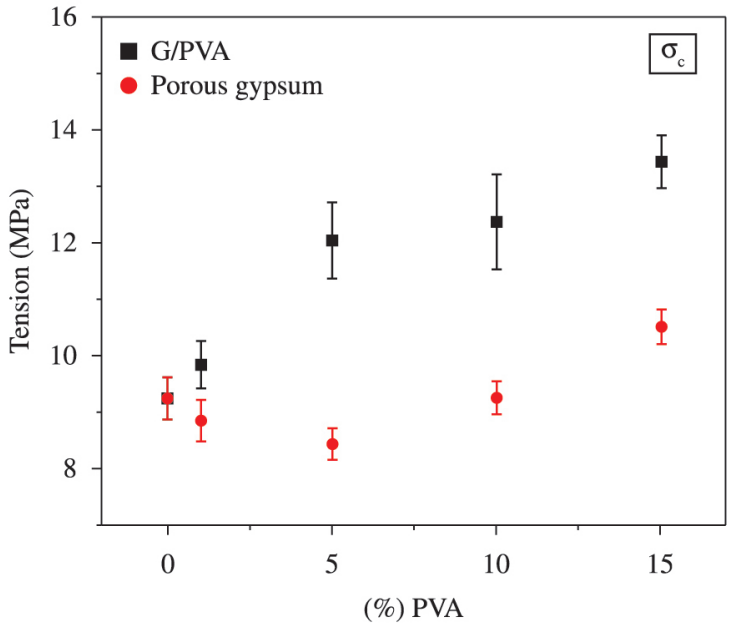

(a)

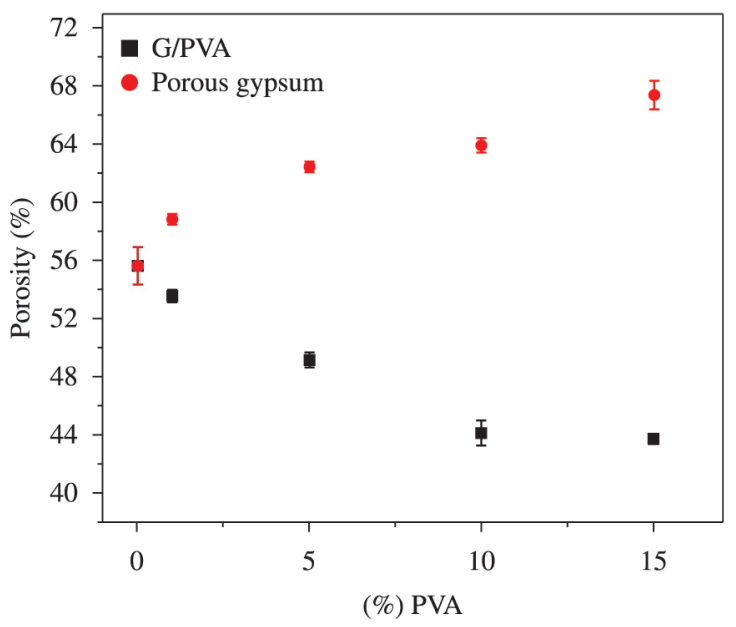

(b)

Figure 3. a)Resistance to compression and b)Geometric porosity, corresponding to different percentages of polymer weight, as well as to the composite before and after the removal of PVA in water.

formation of pores was ascertained. The formation of pores causes a reduction in mechanical strength of the composite, as observed in Figure 3b.

The FTIR spectrum obtained for the combination G/PVA (15\%) showed considerably intense absorption bands that are characteristic for $\mathrm{CaSO}_{4} \cdot 2 \mathrm{H}_{2} \mathrm{O}(444,670,1003$ and $1135 \mathrm{~cm}^{-1}$ for $\mathrm{SO}_{4}^{2-}$ and $595 \mathrm{~cm}^{-1}, 1623 \mathrm{~cm}^{-1}$ for $\left.\mathrm{OH}\right)$ and absorption bands of minimal intensity associated to PVA (1431 and $2927 \mathrm{~cm}^{-1}$ for $-\mathrm{CH}_{3}$ and $1737 \mathrm{~cm}^{-1}$ for $\mathrm{C}=\mathrm{O}$ ) were identified, the latter being eliminated from the spectrum after the treatment of the material in water for the removal of PVA. The analysis regarding the X-ray diffractograms of the sample, ascertained that the polymer did not cause any modification in the characteristic peaks of the dehydrate.

The increase in gypsum resistance resulting from the addition of PVA can also be observed during the machining of the composite blocks to obtain prototypes, as seen in Figure 4. The prototypes developed from the G/PVA
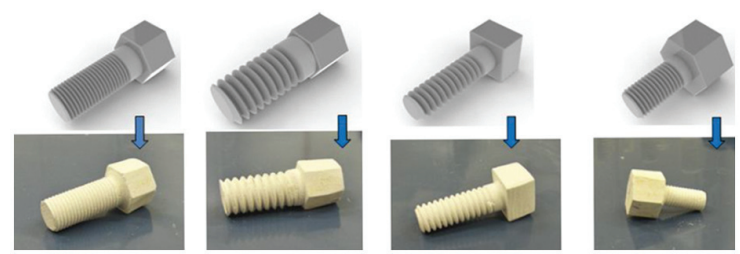

Figure 4. Three-dimensional designs created with SolidWorks 2010 and the corresponding screws machined from Gypsum/PVA composites.

composite (15\%) were obtained based on three-dimensional screw-shaped designs created with the SolidWork 2010 software program.

\subsection{Characterization of porous hydroxyapatite}

Figure 5 shows the infrared spectrums obtained after different reaction times applied during the study of the 
conversion of porous gypsum into porous HAp. As can be observed in the spectrum shown in Figure $5 \mathrm{~B}$, there is a change in the absorption bands after 8 hours reaction time, when the formation of bands for HAp can be verified, as shown in Table 1 . At 24 hours reaction time, a reduction of bands for gypsum can be verified in the spectrum in Figure 5C, giving place to the formation of more intense bands associated to HAp. Also, there is a reduction of bands related to the water attributed to the dihydrate. The complete conversion can be ascertained in Figure 5D, where absorption bands attributed to the phosphate group can be verified, in addition to a band at $1406 \mathrm{~cm}^{-1}$ associated to the $\mathrm{CO}_{3}{ }^{2-}$ group, what characterizes the formation of a carbonated HAp.

The diffractograms in Figure 6 show the peaks regarding the analyzed samples at different times of the conversion of gypsum into HAp. Figure 6A corresponds to the diffractogram of porous gypsum before the reaction. Observing the diffractogram in Figure 6B, the presence of several peaks for HAp can be verified, as shown in Table 2. Analyzing the diffractogram obtained for the sample at 24 hours conversion time shown in, Figure 6C, the presence of intense peaks attributed to the dihydrate can still be ascertained, while there are only peaks of minimal intensity associated to HAp. For 36 hours reaction time, the predominance of peaks characteristic for HAp can be verified in Figure 6D, being related to their respective crystallographic planes as shown by Table 2 .

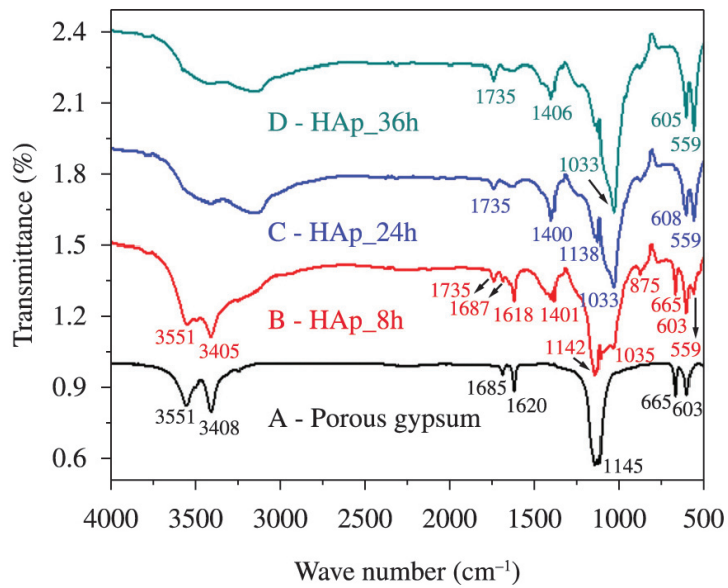

Figure 5. Infrared spectrums: A) for porous gypsum; B), C) and D) for HAp after 8, 24 and 36 hours conversion time, respectively.

Table 1. Absorption regarding functional groups assigned to HAp and dihydrated gypsum.

\begin{tabular}{ccc}
\hline $\begin{array}{c}\text { Reaction } \\
\text { time }\end{array}$ & $\begin{array}{c}\text { Absorption attributed } \\
\text { to }\left(\mathbf{P O}_{\mathbf{4}}{ }^{3-}\right) \text { associated } \\
\text { to HAp }\end{array}$ & $\begin{array}{c}\text { Absorption attributed } \\
\text { to }\left(\mathbf{S O}_{\mathbf{4}}{ }^{2-}\right) \text { associated to } \\
\text { gypsum }\end{array}$ \\
\hline $8 \mathrm{~h}$ & $559,1035 \mathrm{~cm}^{-1}$ & $603,665,1142 \mathrm{~cm}^{-1}$ \\
$24 \mathrm{~h}$ & $559,608,1033 \mathrm{~cm}^{-1}$ & $1138 \mathrm{~cm}^{-1}$ \\
$36 \mathrm{~h}$ & $559,605,1033 \mathrm{~cm}^{-1}$ & ---- \\
\hline
\end{tabular}

The morphology of the different samples of porous HAp (8, 24 and 36 hours of conversion) can be seen by means of micrographs related to the fracture surface of the blocks, shown in Figure 7. It can be observed that after 8 hours reaction time (Figure 7a), the predominant micro-structure of the sample relates to the dihydrate, as its prismatic crystal shape can be noted. From 24 hours conversion time on, Figure $7 \mathrm{~b}$, the material morphology changes completely, presenting particles of circular shape. High porosity can also be observed in the micro-structure of Figure 7c, for 24 and 36 hours reaction time, respectively.

The EDS analysis obtained for HAp_36h is shown in Figure $7 \mathrm{~d}$, making it possible to confirm the presence of the chemical elements $\mathrm{Ca}$ and $\mathrm{P}$, which are characteristic for HAp.

The mechanical strength $\left(\sigma_{\mathrm{C}}\right)$ and the porosity of porous $(\varepsilon)$ HAp produced after 36 hours reaction time were measured and the obtained values are $3.5 \pm 0.07 \mathrm{MPa}$ and $80 \pm 0.88 \%$, respectively. Therefore, it is possible to attribute the low value for mechanical strength of the HAp to its elevated porosity.

The conversion reaction of gypsum into HAp is based on a diffusion process of the ions present in the reaction medium. The development of the reaction is summarized in accordance to Equation 2.

$10 \mathrm{CaSO}_{4} \cdot 2 \mathrm{H}_{2} \mathrm{O}+6\left(\mathrm{NH}_{4}\right)_{2} \mathrm{HPO}_{4}+8 \mathrm{NH}_{4} \mathrm{OH} \rightarrow$
$\mathrm{Ca}_{10}\left(\mathrm{PO}_{4}\right)_{\mathrm{x}}\left(\mathrm{CO}_{3}\right)_{\mathrm{y}}(\mathrm{OH})_{7}+10\left(\mathrm{NH}_{4}\right)_{2} \mathrm{SO}_{4}+26 \mathrm{H}_{2} \mathrm{O}$

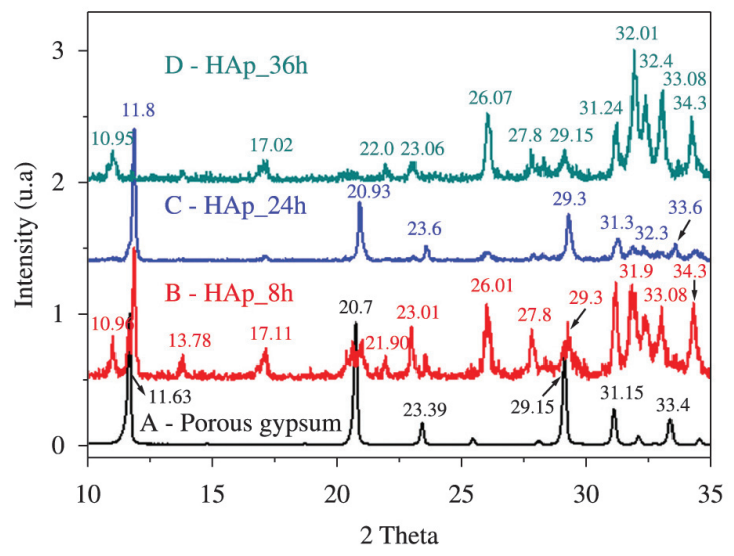

Figure 6. X-ray diffractograms: A) for porous gypsum; B), C) and D) for HAp after 8, 24 and 36 hours conversion time, respectively.

Table 2. Crystallographic planes related to HAp and to dihydrate gypsum.

\begin{tabular}{cccc}
\hline $\begin{array}{c}\text { Crystal } \\
\text { planes of } \\
\text { HAp }\end{array}$ & $\mathbf{2 \theta}$ & $\begin{array}{c}\text { Crystal } \\
\text { planes of the } \\
\text { dihydrate }\end{array}$ & $\mathbf{2 \theta}$ \\
\hline$(002)$ & $26.07^{\circ}$ & $(020)$ & $11.8^{\circ}$ \\
$(102)$ & $27.8^{\circ}$ & $(021)$ & $20.7^{\circ}$ \\
$(210)$ & $29.1^{\circ}$ & $(040)$ & $23.3^{\circ}$ \\
$(112)$ & $32.01^{\circ}$ & $(111)$ & $27.8^{\circ}$ \\
$(300)$ & $33.08^{\circ}$ & $(041)$ & $29.15^{\circ}$ \\
$(202)$ & $34.3^{\circ}$ & $(221)$ & $31.1^{\circ}$ \\
\hline
\end{tabular}




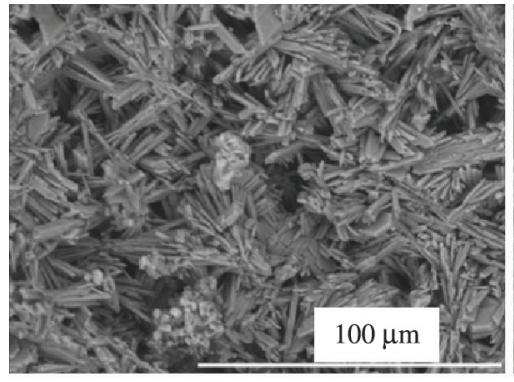

(a)

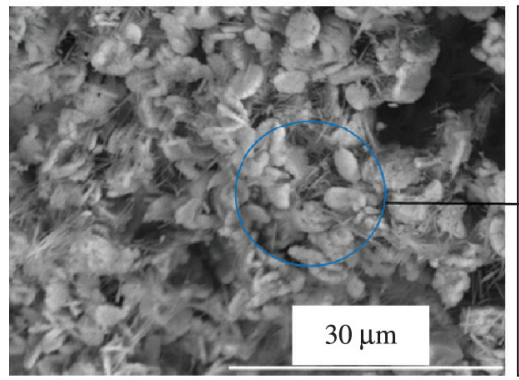

(d)

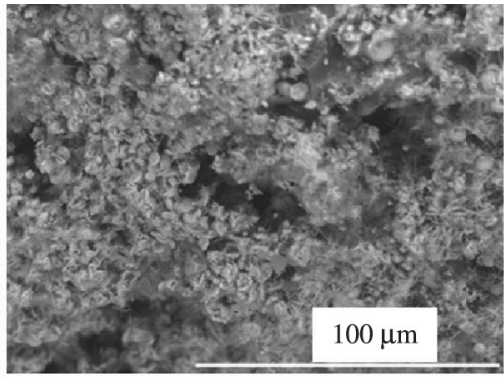

(b)

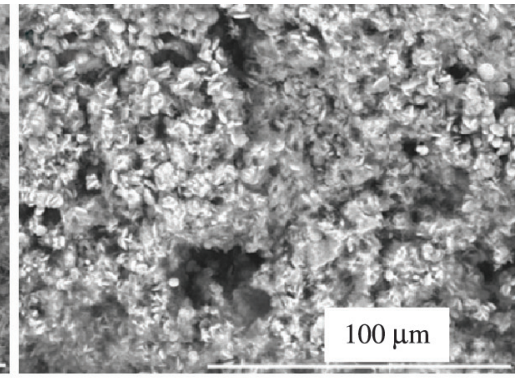

(c)

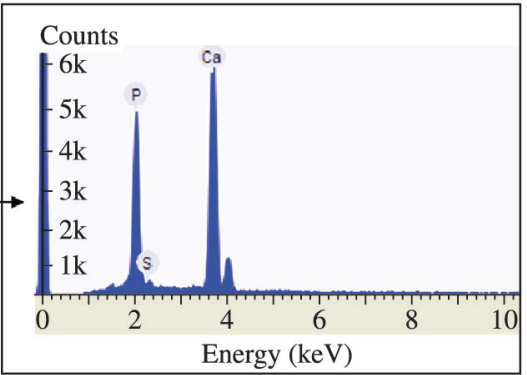

Figure 7. Micrographs regarding the fracture area of the blocks after different conversion times. Being: a) HAp_8h; b) HAp_24h; c) HAp_36h and d) Hap_36h with corresponding EDS analysis.

As can be observed in Equation 2, the conversion reaction occurs through the release of $\mathrm{SO}_{4}{ }^{2-}$ ions in the reaction medium, what gives origin to sulfuric acid, disturbing the equilibrium and favoring the formation of reactants. Due to this occurrence, ammonium hydroxide solution $\left(6.0 \mathrm{~mol} . \mathrm{L}^{-1}\right)$ is added in order to neutralize this acid, generating ammonium sulfate as a product. Other factors considered in the conversion process are the solubility product and the Gibbs free energy of the species. Observing the values for Kps of the dihydrate and the HAp, namely, $1.35 .10^{-4}$ and $3.37 .10^{-58}$ both at $25^{\circ} \mathrm{C}$ respectively ${ }^{14,16}$, it can be verified that the solubility of the dihydrate is much higher than the one of the HAp. Therefore, the HAp phase has a greater tendency to be formed during the reaction, to the detriment of the dihydrate, which presents a greater facility to dissociate, generating the $\mathrm{Ca}^{2+}$ ions in the reaction.

The data attributed to Gibbs free energy for the formation of the $\mathrm{HAp}^{17}$ and the dihydrate ${ }^{14}$, namely else, $\Delta \mathrm{G}_{\mathrm{f}}^{\circ}=-12.590,50 \mathrm{KJ} \cdot \mathrm{mol}^{-1}$ and $\Delta \mathrm{G}_{\mathrm{f}}^{\circ}=-429,63 \mathrm{KJ} \cdot \mathrm{mol}^{-1}$, respectively, when associated to Equation 2, confirm a tendency to forming the product, as the formation of HAp releases more energy, providing a stable product.

\section{Conclusion}

Based on the obtained results, it can be ascertained that the addition of the PVA polymer to gypsum results in a greater mechanical resistance of the material, making it capable of being machined for prototype production. The used methodology of chemical conversion of solid bodies of porous gypsum into porous HAp blocks has proven efficient, seeing that the characterization of the materials showed the predominance of HAp in the samples with application of the following parameters: $\left(\mathrm{NH}_{4}\right)_{2} \mathrm{HPO}_{4} 0.5 \mathrm{~mol} . \mathrm{L}^{-1}$ solution, $\mathrm{NH}_{4} \mathrm{OH} 6.0 \mathrm{~mol} . \mathrm{L}^{-1}$ solution, temperature of $100^{\circ} \mathrm{C}$ and 36 hours reaction time. Based on these results it was possible to obtain a screw-shaped HAp prototype which maintained its form unaltered after the conversion process.

\section{Acknowledgements}

The authors gratefully acknowledge the Gesso Mineral Industry, FACEPE and CAPES.

\section{References}

1. Andrade MC, Filgueiras MRT and Ogasawara T. Nucleation and growth of hydroxyapatite on titanium pretreated in $\mathrm{NaOH}$ Solution: Experiments and thermodynamic explanation. Journal of Biomedical Materials Research. 1999; 46(4):441446. http://dx.doi.org/10.1002/(SICI) 1097 4636(19990915)46:4\%3C441::AID-JBM1\%3E3.0.CO;2-9
2. Ravaglioli A and Krajewski A. Bioceramics: Materials, Properties, Applications. New York: Chapman \& Hall; 1992. http://dx.doi.org/10.1007/978-94-011-2336-5

3. Hench LL and Wilson J. An Introduction to Bioceramics. Advanced Series in Ceramics. London: World Scientific; 1999.

4. Trommer RM, Santos LA and Bergmann CP. Obtenção e Caracterização de Revestimentos de Hidroxiapatita 
Sobre Substratos de Aço Inoxidável 316L Utilizando a Técnica de Deposição Química de Vapor. In: Anais do $17^{\circ}$ Congresso Brasileiro de Engenharia e Ciência dos Materiais - CBECIMat; 2006, Foz do Iguaçu. Foz do Iguaçu; 2006.

5. Rigo ECS, Gehrke SA and Carbonari M. Síntese e Caracterização de Hidroxiapatita Obtida pelo Método da Precipitação. Revista Dental Press de Periodontia e Implantologia. 2007; 1(3):39-50.

6. Maia M, Klein ES, Monje TV and Pagliosa C. Reconstrução da Estrutura Facial por Biomateriais: Revisão de Literatura. Revista Brasileira de Cirurgia Plástica. 2010; 25(3):566-572. http://dx.doi.org/10.1590/S1983-51752010000300029

7. Canut MMC. Estudo da Viabilidade do Uso do Resíduo Fosfogesso como Material de Construção. [Dissertação]. Belo Horizonte: Universidade Federal de Minas Gerais; 2006.

8. Santos RD. Estudo Térmico e de Materiais de um Compósito à Base de Gesso e EPS para Construção de Casas Populares. [Dissertação]. Natal: Universidade Federal do Rio Grande do Norte; 2008.

9. Chemistry Aldrich. Manual de Produtos Químicos. São Paulo; 2009-2010.

10. Harada E and Pimentel LL. Estudo da Viabilidade do Reaproveitamento de Gesso-Queima Lenta. In: Anais do XIV Encontro de Iniciação Científica da PUC; 2009; São Paulo. São Paulo; 2009.
11. Fernandes DM. Estudo da Estabilidade Térmica de Blendas de Poli(álcool vinílico)/lignina Modificada. [Dissertação]. Paraná: Universidade Estadual de Maringá; 2005.

12. Akiyoshi MM, Silva AP, Silva MG and Pandolfelli VC. Condutividade Térmica e sua Correlação com a Temperatura e a Massa Específica Volumétrica de Materiais Refratários Sílico-Aluminosos e Aluminosos. Cerâmica. 2001; 47:301. http://dx.doi.org/10.1590/S0366-69132001000100005

13. Aranha IB and Lucas EF. Poli(Álcool Vinílico) Modificado com Cadeias Hidrocarbônicas: Avaliação do Balanço Hidrófilo/ Lipófilo. Polímeros. 2001; 11(4):174-181. http://dx.doi. org/10.1590/S0104-14282001000400007

14. Fernandes FRF, Da Luz AB and Castilhos ZC. Agrominerais para o Brasil. Rio de Janeiro: Centro de Tecnologia Mineral; 2010.

15. Kanno WM. Propriedades Mecânicas do Gesso de Alto Desempenho. [Tese]. São Carlos: Universidade de São Paulo; 2009.

16. Resende CX. Estudo Teórico-Experimental de Duas Soluções para Testes de Bioatividade e Revestimento de Metais. [Dissertação]. Rio de Janeiro: Universidade Federal do Rio de Janeiro; 2007.

17. Iglesia AL. Estimating the thermodynamic properties of phosphate minerals at high and low temperature from the sumo of constituent units. Estudos Geológicos. 2009; 65(2):109-119. http://dx.doi.org/10.3989/egeol.39849.060 